\title{
Cell Bank
}

National Cancer Institute

\section{Source}

National Cancer Institute. Cell Bank. NCI Thesaurus. Code C15893.

Repository of cell samples 